\title{
Effect of the Deposition Conditions of Platinum Electrodes on their Performance as Resistive Heating Elements
}

\author{
Andrei Ionut Mardare $^{\mathrm{a}}$, Cezarina Cela Mardare ${ }^{\mathrm{a}}$, Ednan Joanni $^{\mathrm{a}, \mathrm{b}_{*}}$ \\ aINESC-Porto, Unidade de Optoelectrónica e Sistemas Electrónicos, \\ Rua do Campo Alegre 687, 4169-007 Porto, Portugal \\ ${ }^{b}$ Universidade de Trás-os-Montes e Alto Douro, Departamento de Física, \\ 5001-911 Vila Real, Portugal
}

Received: September 16, 2003; Revised: March 25, 2004

\begin{abstract}
The performance of different platinum electrodes used as resistive heating elements was studied. Pt films having different thickness were deposited by RF magnetron sputtering at room temperature followed by post-deposition annealing at $700^{\circ} \mathrm{C}$ or made in-situ at $700^{\circ} \mathrm{C}$. The Pt films were deposited over oxidized silicon, using $\mathrm{Ti}$ or $\mathrm{Zr}$ buffer layers. The resistance dependence on temperature was studied by applying increasing currents (up to 2A) to the Pt films. Changes in the microstructure of the $\mathrm{Pt}$ films account for the changes in the temperature coefficient of resistance as a function of the deposition parameters. The maximum substrate temperature $\left(675^{\circ} \mathrm{C}\right)$ was obtained when using $200 \mathrm{~nm}$ Pt films deposited at $700{ }^{\circ} \mathrm{C}$ over Ti, with a power consumption of only $16 \mathrm{~W}$.
\end{abstract}

Keywords: joule heating, platinum, thin films, bottom electrodes

\section{Introduction}

Post deposition heat treatments on thin films deposited at low temperature are an important step in obtaining ceramic films with the required crystalline phases. Different heating methods can have a very big influence on the final material properties, therefore many efforts are made to find the optimum conditions for heat treatment. For instance, slow furnace annealing and rapid thermal annealing methods can give distinct results regarding grain size and phases present in the films ${ }^{1-3}$.For high temperature crystallization heat treatments platinum bottom electrodes are important due to their high stability and oxidation resistance. Platinum films are also used as heating elements in resistive heaters, and their temperature coefficient of resistance is exploited in temperature sensors, gas sensors and anemometers $^{4-7}$. In a previous report we presented a simple method for crystallizing ceramic thin films using the platinum bottom electrodes as resistive heating elements ${ }^{8}$.This bottom electrode crystallization (BEC) method is simple and has several advantages over the other crystallization techniques, such as very low power consumption and the possibility of using high heating rates with precise temperature control.

In this paper we report the effect of the preparation con-

*e-mail: ednan@utad.pt ditions of the platinum thin films and adhesion layers on their performance as resistive heating elements for the crystallization of ceramic thin films using the Joule effect.

\section{Experimental}

The samples used for the study of the platinum heating elements for the BEC method consisted of $\mathrm{Pt} / \mathrm{Ti}(\mathrm{Zr}) / \mathrm{SiO}_{2} / \mathrm{Si}$ stacks. For sample preparation, silicon wafers with (100) orientation were cut into $1 \times 1 \mathrm{~cm}^{2}$ pieces and oxidized in wet oxygen flow for $72 \mathrm{~h}$ at $950{ }^{\circ} \mathrm{C}$ in order to obtain a $2 \mu \mathrm{m}$ layer of $\mathrm{SiO}_{2}$. On those substrates, titanium and zirconium films $30 \mathrm{~nm}$ thick, deposited at $200^{\circ} \mathrm{C}$, were alternatively used for enhancing the adhesion between the silica and the platinum films. All the metallic layers were deposited by RF magnetron sputtering in argon atmosphere. The targets used had a 2 in diameter and the deposition power and pressure were kept constant at $150 \mathrm{~W}$ and $10^{-2}$ mbar respectively. The thickness of the films was measured in real time using an oscillating quartz crystal thickness monitor. All the platinum films were heat treated at $700{ }^{\circ} \mathrm{C}$ in order to minimize subsequent microstructural changes during the experiments. One series of $\mathrm{Pt}$ films was deposited in situ at $700{ }^{\circ} \mathrm{C}$ while the other series 
was deposited at room temperature and heat treated in air at $700{ }^{\circ} \mathrm{C}$ for $10 \mathrm{~min}$ using a $1000 \mathrm{~W}$ halogen lamp heater with $10^{\circ} \mathrm{C} / \mathrm{s}$ heating and cooling rates. The preparation conditions for the electrodes are presented in Table 1.

Electrical contacts were made on two opposite edges of the platinum films using $0.5 \mathrm{~mm}$ diameter tungsten wires; the distance between the contacts was $8 \mathrm{~mm}$. This setup allows a bigger contact area compared with the one previously reported ${ }^{8}$, avoiding localized hot spots and making unnecessary the use of silver paste. The samples were placed over a high temperature ceramic fiber insulator. The temperature obtained due to the Joule effect was monitored in real time using a type $\mathrm{K}$ thermocouple with $0.3 \mathrm{~mm}$ thick wires. The setup is shown schematically in Fig. 1.

A DC power supply (Kepco 60-2 DM) with an upper current limit of $2 \mathrm{~A}$ was used for applying currents to the platinum films. A multimeter (HP 34401 A) was used for reading the voltage from the thermocouple. The setup was controlled using a LabView ${ }^{\circledR}$ program which was set to increase the applied current from 0 to $2 \mathrm{~A}$ with a step of $0.02 \mathrm{~A}$ and to measure the voltage for each value of the current in order to obtain the value of the resistance as a function of temperature. For ensuring a thermal equilibrium of the whole setup during the resistance measurements, the current values were modified periodically at every $20 \mathrm{~s}$.

The microstructures of the samples were analyzed using X-ray diffraction (Siemens D5000) and scanning electron microscopy (JEOL JSM-6301F).

\section{Results and Discussion}

X-ray diffraction scans performed on all samples showed only the presence of the Pt (111) peak. Fig. 2. shows the resistance as a function of temperature for Pt films $200 \mathrm{~nm}$, $300 \mathrm{~nm}$ and $400 \mathrm{~nm}$ thick deposited at room temperature over Ti and heat treated at $700{ }^{\circ} \mathrm{C}$ in air. With the increase of the thickness of the Pt films, both the room temperature resistance and the temperature coefficient of resistance decreased. As a consequence, the highest temperature that

Table 1. Preparation conditions for the electrodes.

\begin{tabular}{lcccc}
\hline $\begin{array}{l}\text { Sample } \\
\text { name }\end{array}$ & $\begin{array}{c}\text { Adhesion } \\
\text { material }\end{array}$ & $\begin{array}{c}\text { Platinum } \\
\text { thickness } \\
(\mathrm{nm})\end{array}$ & $\begin{array}{c}\text { Platinum } \\
\text { deposition } \\
\text { temperature } \\
\left({ }^{\circ} \mathrm{C}\right)\end{array}$ & $\begin{array}{c}\text { Post } \\
\text { deposition } \\
\text { heat treatment }\end{array}$ \\
\hline Ti200 & $\mathrm{Ti}$ & 200 & 700 & - \\
Ti300 & & 300 & 700 & - \\
Ti400 & & 400 & 700 & - \\
Ti200H & & 200 & room & 10 min at $700{ }^{\circ} \mathrm{C}$ \\
Ti300H & & 300 & room & 10 min at $700{ }^{\circ} \mathrm{C}$ \\
Ti400H & & 400 & room & 10 min at $700{ }^{\circ} \mathrm{C}$ \\
\hline Zr200 & Zr & 200 & 700 & - \\
Zr300 & & 300 & 700 & - \\
\hline
\end{tabular}

could be achieved with the maximum current ( $2 \mathrm{~A}$ ) decreased from $650{ }^{\circ} \mathrm{C}$ for the $200 \mathrm{~nm}$ film to $125^{\circ} \mathrm{C}$ for the $400 \mathrm{~nm}$ film. The power consumption necessary for achieving the maximum temperature with the $200 \mathrm{~nm}$ film was $15 \mathrm{~W}$, showing the high energy efficiency of the BEC method due to the small mass of the sample and the direct contact between the Pt film and the Si substrate.

The results obtained for $\mathrm{Pt}$ films deposited at $700{ }^{\circ} \mathrm{C}$ over $\mathrm{Ti}$ and $\mathrm{Zr}$ buffer layers are shown in Fig. 3. Comparing films with the same thicknesses, the room temperature resistance and the temperature coefficient of resistance for the Pt films deposited over Ti were higher than those deposited over $\mathrm{Zr}$. The maximum temperature achieved using Ti was $675^{\circ} \mathrm{C}$, with a power of $16 \mathrm{~W}$, while the maximum temperature for the corresponding $\mathrm{Zr}$ film was $450{ }^{\circ} \mathrm{C}$. The lowest value of

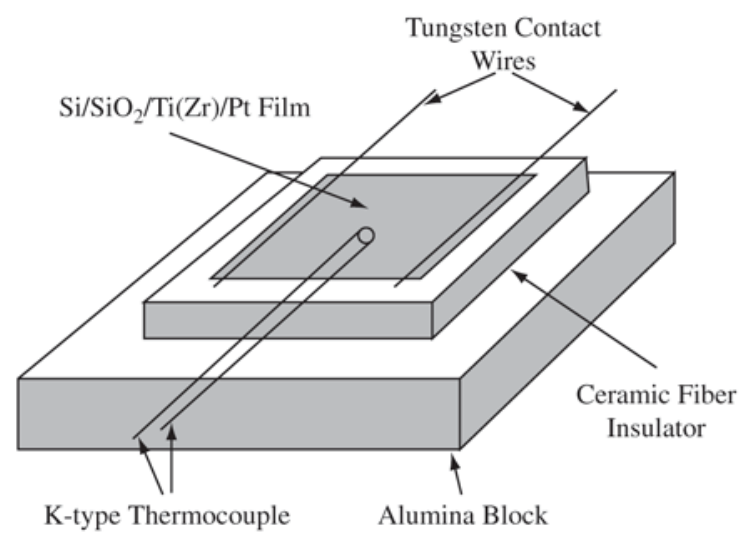

Figure 1. Experimental setup for measuring the resistance of the films as a function of temperature.

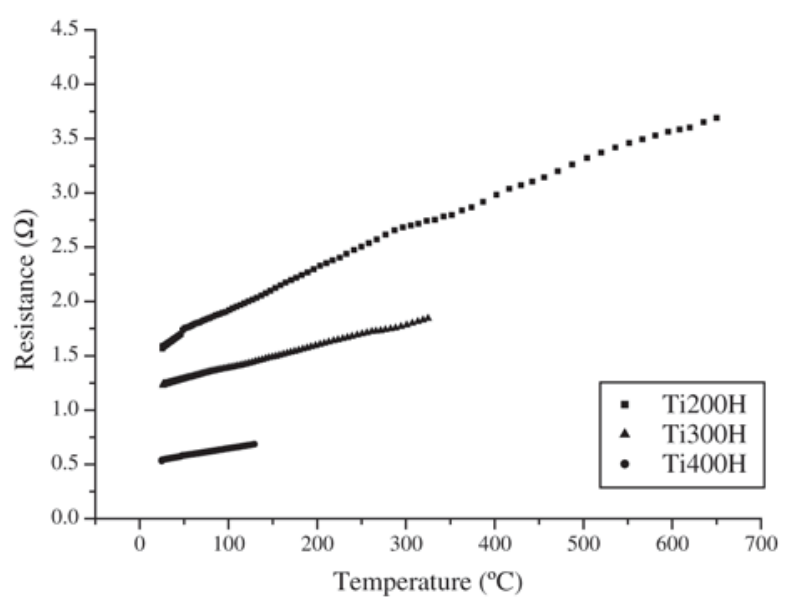

Figure 2. Variation of the resistance as a function of temperature for Pt films $200 \mathrm{~nm}, 300 \mathrm{~nm}$ and $400 \mathrm{~nm}$ thick deposited at room temperature over $\mathrm{Ti}$ and heat treated for $10 \mathrm{~min}$ at $700{ }^{\circ} \mathrm{C}$. 
temperature recorded at the maximum current of $2 \mathrm{~A}$ was $125^{\circ} \mathrm{C}$ and it was measured on the $400 \mathrm{~nm} \mathrm{Pt}$ film deposited at $700{ }^{\circ} \mathrm{C}$ over Ti. The room temperature value of resistance for this film was low, being measured as only $0.45 \Omega$

The scanning electron microscope photographs of the surfaces of two Pt films deposited over Ti are shown in Fig. 4. All the films deposited at room temperature and heat treated for $10 \mathrm{~min}$ at $700{ }^{\circ} \mathrm{C}$ were porous and in Fig. 1a can see the voids between the grains. In contrast, the films deposited at

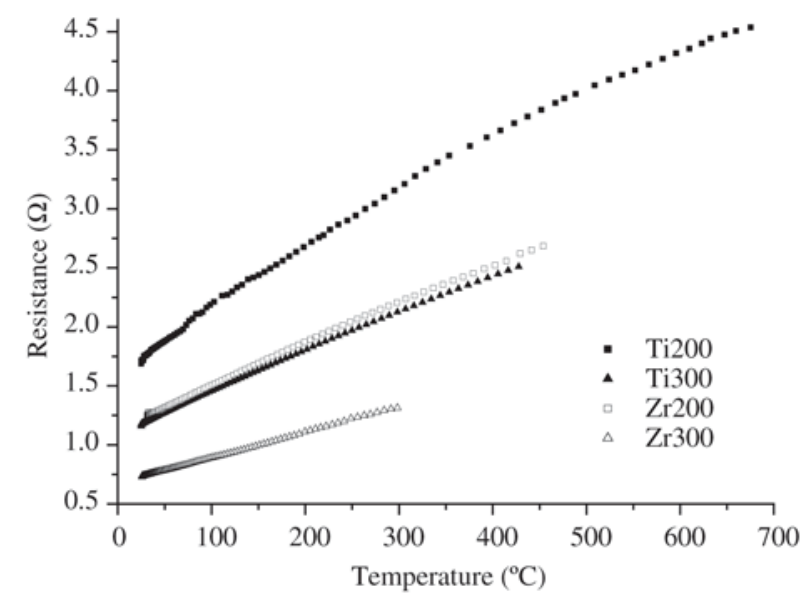

Figure 3. Variation of the resistance as a function of temperature for Pt films $200 \mathrm{~nm}$ and $300 \mathrm{~nm}$ thick deposited at $700{ }^{\circ} \mathrm{C}$ over Ti and $\mathrm{Zr}$.
$700{ }^{\circ} \mathrm{C}$ were denser and had slightly bigger grain sizes as illustrated in Fig. 1b.

Considering the microstructure of these films, the results shown on Figs. 2 and 3 for the Pt films deposited over Ti can be explained as follows: in the Pt films deposited at room temperature, Ti diffusing through the Pt grain boundaries during the post deposition heat treatment is oxidized. The volume expansion due to $\mathrm{TiO}_{\mathrm{x}}$ formation force them to open as shown in Fig. $4 a^{9}$. Due to thermal expansion, when currents are applied to these films, the volume of the grains increase, having as a result an increase in the contact surface between the grains. As a consequence, the temperature coefficient of resistance is lower than in the case of the $\mathrm{Pt}$ films deposited in argon at high temperature. For the Pt films deposited at $700{ }^{\circ} \mathrm{C}$ (Fig. 4b), the films are denser and the $\mathrm{Ti}$ is not oxidized because the deposition is carried out in argon, without breaking the vacuum between the deposition of the metals. Only when the current is applied to these films in air, the Ti in the grain boundaries oxidizes, increasing both the resistance of the films and their temperature coefficient of resistance.

Figure 5 shows the surface of a $\mathrm{Pt}$ film deposited at $700{ }^{\circ} \mathrm{C}$ over $\mathrm{Zr}$. In this case the $\mathrm{Pt}$ is denser and has bigger grains than the ones deposited over Ti. Accordingly, the resistance of these films is lower and the temperature coefficient of resistance is also lower due to the fact that $\mathrm{Zr}$ does not diffuse through the Pt film, as previously reported ${ }^{9}$.

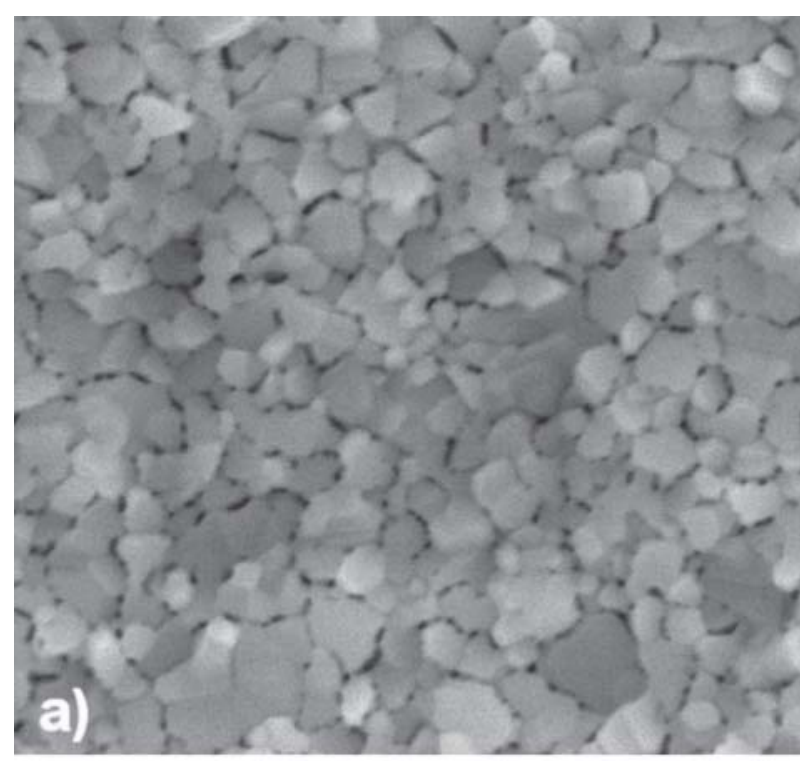

SE1 - PA4_ $\overline{0.50 \mu \mathrm{m}} \quad$ CEMUD $\times 35000 \mathrm{E} 0=15 \mathrm{KV}$ WD $=8 \mathrm{~mm}$

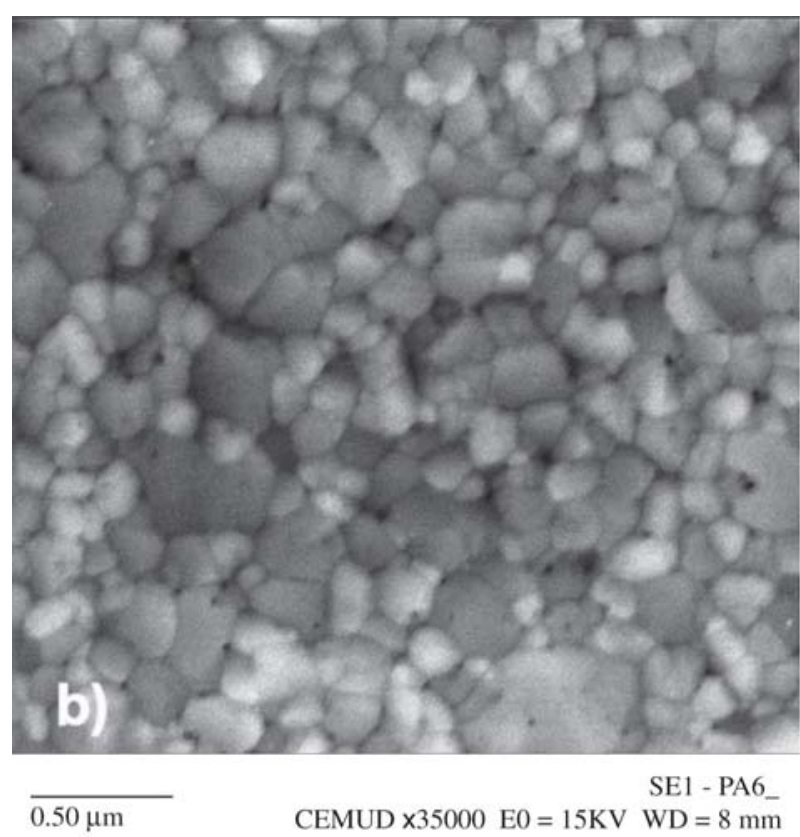

Figure 4. a) Scanning electron microscope image of the surface of the Pt film deposited over Ti at room temperature and heat treated at $700{ }^{\circ} \mathrm{C}$; b) Scanning electron microscope image of the surface of the Pt film deposited over Ti at $700{ }^{\circ} \mathrm{C}$. 


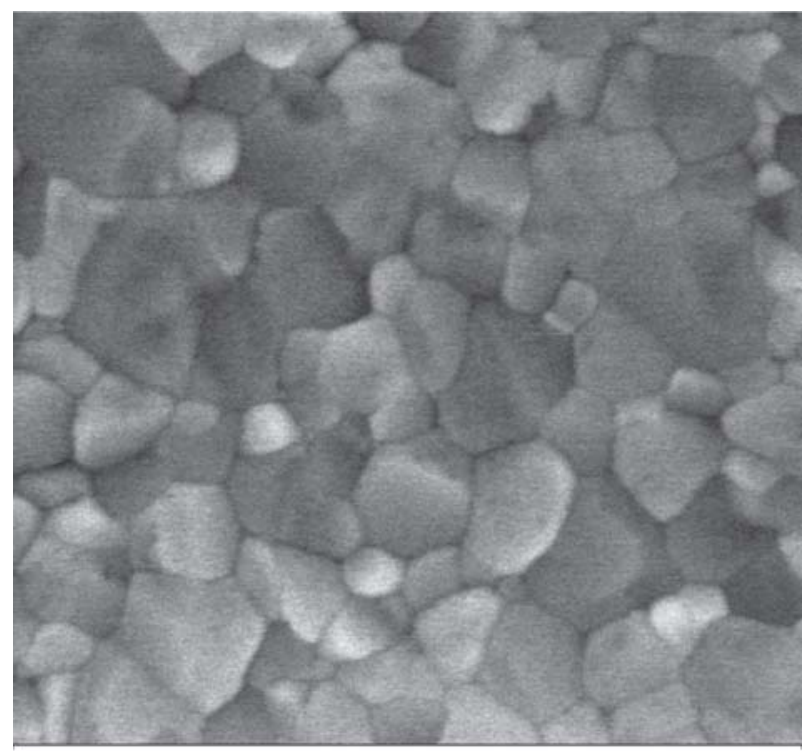

SE1 - PA9

$0.50 \mu \mathrm{m}$ CEMUD $\times 35000 \mathrm{E} 0=15 \mathrm{KV} \quad \mathrm{WD}=8 \mathrm{~mm}$

Figure 5. Scanning electron microscope image of the surface of the Pt film deposited over $\mathrm{Zr}$ at $700{ }^{\circ} \mathrm{C}$.

\section{Conclusions}

In summary, the effect of different deposition conditions of $\mathrm{Pt} / \mathrm{Ti}(\mathrm{Zr})$ thin-films on the maximum temperature achievable on low-current heating elements was studied as a function of the thickness of the platinum films and of the buffer layers used (Ti, Zr). Increasing the current up to $2 \mathrm{~A}$, the resistance of the films made under different conditions was analyzed as a function of the temperature and the results were correlated with the microstructure of the films. The maximum temperature, $675^{\circ} \mathrm{C}$, was obtained when $200 \mathrm{~nm}$ Pt films were deposited at $700{ }^{\circ} \mathrm{C}$ over Ti adhesion layers.

The platinum films $200 \mathrm{~nm}$ thick are more suitable for the crystallization of ceramic thin films due to the fact that higher heating rates and/or higher temperatures can be achieved using a low current power supply. The $\mathrm{Zr}$ underlayer has the advantage of having a low diffusion co- efficient in Pt, avoiding unwanted contaminations in the ceramic film to be crystallized when deposited over the platinum electrodes. On the other hand, from the point of view of thermal performance of the heating element, the Ti films give better results. The BEC method is very efficient, with a very low $(16 \mathrm{~W})$ power consumption recorded at 675 ${ }^{\circ} \mathrm{C}$. Work is now in progress for applying the BEC method to the crystallization of PZT thin films made by different deposition techniques.

\section{Acknowledgement}

A.I. Mardare and C.C. Mardare would like to acknowledge the financial support from the European Network Project ODUPE (HPRN-CT-200-00045).

\section{References}

1. Lee, J.; Joo, S. Materials Research Society Symposium Proceedings, v. 695, p. 21, 2002.

2. Griswold, E.M.; Weaver, L.; Calder, I.D. Journal of Materials Research, v. 10, n. 12, p. 3149, 1995.

3. Merklein, S.; Berger, A.; Wahl, S.; Grond, W.; Sporn, D. Proceedings of Electroceramics IV, International Conference on Electronic Ceramics and Applications, Aachen, v. 1, p. 309, 1994.

4. Zhang, J.; Nagao, Y.; Kuwano, S.; Ito, Y. Japanese Journal of Applied Physics, v. 36, n. 2, p. 834, 1997.

5. Mailly, F.; Gianni, A.; Bonnot, R.; Temple-Boyer, P.; Pascal-Delannoy, F.; Foucaran, A.; Boyer, A. Sensors and Actuators A, v. 94, n. 1-2, p. 32, 2001.

6. Esch, H.; Huyberechts, G.; Mertens, R.; Maes, G.; Manca, J.; De Ceuninck, W.; De Schepper, L. Sensors and Actuators B, v. 65, n. 1-3, p. 190, 2000.

7. Moritz, W.; Roth, U.; Heyde, M.; Rademann, K.; Reichling, M.; Hartmann. J. Thin Solid Films, v. 391, p. 143, 2001.

8. Joanni, E.; Mardare, A.I.; Mardare, C.C.; Fernandes, J.R.A. Japanese Journal of Applied Physics, v. 42, p. L863 - L865, 2003.

9. Maeder, T.; Sagalowicz, L.; Muralt, P. Japanese Journal of Applied Physics, v. 37, n. 4A, p. 2007, 1998. 